\title{
Pentecostal Churches and Capitalism in a South African Township: Towards a Communism of the Market?
}

\author{
Thibaut Dubarry \\ thibaut.dubarry@gmail.com
}

\begin{abstract}
With reference to two Pentecostal churches in the Kayamandi suburb of Stellenbosch, South Africa, we consider the ways in which capitalism and the Pentecostal spirit interrelate in a contemporary South Africa. We start off by acknowledging that many forms of Pentecostalism now tend to follow the paradigm set by neo-Pentecostalism, and that the same might be true of our two church communities, Revival Fire Ministries, and the Apostolic Faith Mission, even if the latter is more typically regarded as part of the classical Pentecostal movement in South Africa. Then we discuss Pentecostalism and its relationship to the secular domain. We show how Pentecostalism, in contrast to traditional forms of Christianity, is par excellence involved in the immanent/horizontal affairs of believers' lives. Indeed, the market itself appears to be sacralized, implying a transfer of holiness into the secular domain. We conclude with the idea that we have observed a fourth wave of Pentecostalism, anticipating that the golden age of Gesara/Nesara may be considered as a secular faith, forming a Hegelian synthesis of the two socalled secular religions of the $20^{\text {th }}$ century, capitalism and communism. We have analyzed it as an apocatastasis, meaning restoration to the original or primordial condition ${ }^{1}$.
\end{abstract}

1 I hereby testify the following through my 38 semi-structured interviews of Pentecostal believers:

- Honesty in all aspects of the research.

- Accountability in the conduct of research.

- $\quad$ Professional courtesy and fairness in working with others. 


\section{Thibaut Dubarry}

Keywords: Apostolic Faith Mission, Pentecostalism, Revival Fire Ministries, capitalism, communism, South Africa

\section{Introduction}

How could we make sense of two of the main features, which are dramatically shaping sub-Saharan Africa?: The ostentatious triumph of Pentecostal churches and the tremendous, albeit deeply ambivalent and excessively disparate victory of capitalism. Should we consider these two parallel successes as an illustration of antithetical or complementary relations between religion and economics?

The interrelations of these features are complex (McCleary \& Barro 2006), fluctuant, and dualistic. The dynamics of the world capitalist market may increase inequalities (Piketty 2017) and fragment societies, while atomizing individuals. Yet, apparently contrary to this logic, countless churches continue to emerge throughout Africa, which serve to rally believers around cohesive communities.

The primary objective of this article is to analyze the dialectic relation between Pentecostalism and contemporary capitalism within two South African Pentecostal communities located in Kayamandi, a township in Stellenbosch, South Africa. The Apostolic Faith Mission (AFM) has 1.2 million adherents and is the largest Pentecostal church in South Africa, representing 7.6\% of its population (Clark 2015). Revival Fire Ministries Church (RFM) links together approximately 500 members in eight different locations. It was started in 2008 by Tafadzwa Doyce in Zimbabwe.

In reference to this ethnographical research, we intend to demonstrate that there are elective affinities between Pentecostalism and capitalism, while highlighting on the one hand that this successful trend can be analyzed, to some extent as a religious shape of actual capitalism. On the other hand, we would demonstrate that believers' practices, consequently, are conducted with a view to this materialistic horizon and that they commit themselves, at the community scale, to reach this capitalistic ideal.

The general problem underpinning this study is to what extent the religious communities under discussion can combine two apparently contradictory paradigms: A communist and a capitalist pattern. We will argue that

- Good stewardship of research on behalf of others. 
these Pentecostal churches in South African townships correspond to a meltdown between communism and capitalism.

In his social laboratory, Pastor Russel, a religious capitalist entrepreneur analyzed the failure of the neoliberal model and the collapse of the 'neoglobal' capitalism. In a certain way he proposes an anarcho-communism/primitivism as Marx predicted at the end of the collapse of capitalism. In this, he innovates, not strictly speaking by maximizing the profit of his church, but by adapting the demand of his impecunious followers towards an offer that integrates the market data to succeed, which in a noachidist ${ }^{2}$ logic was until then reserved for elected officials. Russel's ambition is to offer his followers the possibility of reaching the opulence of 'Black diamonds', a generic term designating the post-apartheid black class that has reached opulence.

\section{The (neo)-Pentecostal Ethos}

Karl Marx's critique of religion presupposed forms of Christianity that primarily had otherworldly dreams and expectations. Both Roman Catholicism and mainstream Protestantism of early modernity retained a future orientated eschatological theology that preached salvation in the hereafter. The Pentecostal, particularly the neo-Pentecostal ethos of late modernity is quite different (cf. Da Silva 2011). Many authors have noted the adaptation to capitalist norms. The situation might even approximate a complete cooptation of a consumerist ethics with a this-worldly orientation. This would have been anathema to earlier Protestants.

Scholars of global Pentecostalism have generally noted a divergence in the movement of classical Pentecostalism that originated around the turn of century, with the advent of the so-called neo-Pentecostalism since the 1970s. A primary example of this second wave is the Brazilian founded Universal Church of the Kingdom of God. In Africa, one could add many examples such as the large Nigerian originated Winner's Chapel International, and many smaller subsequent additions across the continent. Revival Fire Ministries falls squarely within this category. Spiritual warfare and the idea of good

2 The Hebrew term B'nei Noah can be translated with Noahidism or Noachidism. It is a monotheistic Jewish religious movement based upon the Seven Laws of Noah. 


\section{Thibaut Dubarry}

and evil spirits controlling people's lives are part and parcel of the theology that underpins this movement. However, more pertinent to the theme of this article is the

Theology of Prosperity - that regards wealth as an external proof of God's blessing in the life of the faithful. An intra-worldly eschatonlogy that, in practice, breaks with the Apocalyptic Christian understanding of time and brings retribution or salvation to the faithful's present moment, not leaving them only for heaven and for life after death (Da Silva 2011:69).

Since neo-Pentecostalism has determined the religious market trajectory to such an extent in many places, such as Brazil and Nigeria, and perhaps also increasingly in South Africa, it is this ethos rather than that of classical Pentecostalism that should be considered in our analysis of contemporary religious movements. Citing Campos (1997), a Brazilian theologian, Da Silva refers to a 'Neo-Pentecostal mentality' that infiltrates all religiosity where it has become predominant, "visible in most people, irrespective of their institutional affiliation' (Da Silva 2011:70). Hence, to concretize this to our context, even the AFM with its roots in classical Pentecostalism may exhibit a Neo-Pentecostal ethos in the current climate of consumerist capitalism.

How could we further describe this ethos? One aspect is that it is thoroughly globalized (cf. Anderson 2004) and not tied to any Western or neo-Imperial globalization agenda. Another point worth making is that it cuts across a diversity of social classes with some churches catering to students and educated upwardly mobile younger people, while 'small store front churches in slums cater to the urban poor' (Lewison 2011:37). Churches exhibiting this ethos 'are often centred on the personality cult of a charismatic leader, most of whom are highly educated bearing striking similarities to successful CEOs' (Lewison 2011:37). The case of the RFM again seems typical with the charismatic and polished Pastor Russel at the helm (more about him below).

In a deeper analysis of this movement, taking his cue from the Polish-born sociologist Zygmunt Bauman, Da Silva refers to the metaphor of a 'liquid church' to describe the interaction between neo-Pentecostalism and consumerism: 'For Bauman, the consumerist demand includes in its "survival kit" the task that the individuals themselves must make themselves worthy of 
belonging to the environment where they long to belong: thus, the individual moves from the condition of being a consumer to the condition of being a product to be consumed' (Da Silva 2011:66). This process occurs particularly through the media and other advertising strategies: ' $[R]$ eligion begins to place itself in society as social status, since it becomes available in the market as a "place of benediction", a "place where God is", "where miracles happen" or a place "of happy people" (Da Silva 2011:67).

\section{Pentecostalism as a Capitalistic Catalyst}

When considering the implications of the neo-Pentecostal ethos for the South African context, there are some helpful resources available. The research document, Under the radar: Pentecostalism in South Africa and its potential social and economic role (Attanasi \& Yong 2012) is an obvious place to start. This document conveys useful empirical data regarding the Pentecostal scene in South Africa. In its interpretation, it relies on a neo-Weberian analysis, which is understandable, given that Peter Berger was an active participant in the project. However, Birgit Meyer, whose work on Ghanaian Pentecostalism has been highly influential in global Pentecostal studies, criticizes Under the radar for going 'too far' in using Max Weber, whose work is applied 'as a model out of context' (Meyer 2007:11). To quote Meyer directly:

If it was Weber's concern to highlight the role of Protestantism in bringing about capitalism, today the question is more complicated, as it requires us to investigate not only how Pentecostalism facilitates capitalism (the causality analysed by Weber), but also how the latter shapes the former, and perhaps most importantly, how both are enmeshed (Meyer 2007:11).

Another potential problem with a neo-Weberian approach is the unstated assumption that contemporary township dwelling Africans suffer from a similar anxiety as Weber's European Protestants regarding the surety, or lack of God's salvation. However, this is an assumption that could not be blithely accepted without further interrogation. Do African Pentecostals really have such inner angst about their spiritual salvation? The document somewhat acknowledges the problematic translatability of the Weberian thesis in a way, 


\section{Thibaut Dubarry}

when it states that 'Black Old Pentecostals [presumably referring here to AFM members, come] perhaps closest to the ideal type of an early "Calvinist" approach to life, although their responses lacked the theological/ doctrinal underpinnings typical of this world view' (Attanasi \& Yong 2008:19).

Many studies on prosperity and Pentecostalism take their cue from the Protestant ethic in one way or another, and while there is certainly some validity to this type of approach, this should be supplemented by a diachronic perspective that recognizes the fact that Christianity in (Southern) Africa was built on the foundations of pre-colonial African religion. Surely, it is worth pointing out that African religions have always been about prosperity and material wellbeing. Rainfall and harvests were some of the major ritual preoccupations in these regions, which utterly concern this-worldly prosperity. One might therefore wonder whether scholars of Pentecostalism are not overemphasizing interpretations drawn from a wider Christian tradition at the expense of local traditions that may have had an enduring influence in spite of being officially supplanted by newer forms. Meyer is one scholar who has originally emphasized this aspect in her impressive work, Translating the devil: Religion and modernity among the Ewe in Ghana (Meyer 1999). Another cogent critique, which emphasizes the enduring presence of African tradition, has been made by theologian David Ngong (2009). A point worth making, is that the classical Christian tradition, including Weber's Protestants remained deeply imbued in a dualistic religious worldview. Salvation resided in an otherworldly eschaton.

The so-called inner-worldly asceticism of early modern Calvinists created better earthly conditions for believers, not because they had rejected an otherworldly salvation, but in spite of not doing so. Their otherworldly focus inspired a frugal thrift in the present, which had material consequences over time (Weber 2013). Therefore, it might just as well be argued that if African Pentecostals also exhibit a propensity for thrift, hard work, discipline, etc., this is not because they are neo-Weberian Protestants, but because they are living Spirit-filled lives within a religious environment that has always prioritized the here and now. This was often in spite of Christian missionaries of an earlier era's attempts to convince them that salvation belongs to a different realm.

There are many exceptions to these neo-Weberian interpretations, of course, apart from the abovementioned. Some of the new anthropologists of 
Christianity take other approaches. The sociologist, Bernice Martin also criticized the over reliance on what she calls the 'market metaphor' in some Pentecostal studies. She provides a necessary nuance in stating:

To argue that Pentecostalism, like Methodism before it, has the atleast-partly-unintended consequence of delivering economic betterment in conditions set by global capitalism is not the same as to argue that Pentecostalism is a kind of ideological fifth column for global capitalism and it is important to keep the distinction clear (Martin 2001:98).

However, this part of the quote still maintains a connection between Pentecostalism and classical Protestantism, in this case Methodism, which is a connection that plays its own role in confusing the issues. What comes next, brings us closer to the nerve center of what is also true for African Pentecostalism: 'Third World Pentecostalism, by contrast with the mainstream modern Western Christian churches, tends to make little distinction between spiritual, bodily and material well-being' (Martin 2006:68). Martin continues to affirm the significance of the black African 'spiritual tradition' within transatlantic Pentecostalism as something 'that had neither been extinguished not fully harnessed by the European Christianity imposed by the colonial rulers' (Martin 2001:99).

Martin also makes some valuable comments potentially in support of our contention regarding the meltdown between capitalism and communism (see below) when she mentions the fact that conversions specifically among Latin American women, are less about the individual self than about the wellbeing of their families (Martin 2001:108). The point is that a wider group benefits than just the individual member, and it fits our thesis that the church itself becomes an extended family. Tithing, such an important aspect of both churches we visited in Kayamandi, and for much of Pentecostalism in general, is advertised as a contribution that benefits the church. For example, at the AFM we heard about several ambitious building projects on the church premises. Obviously, the point of such advertising, apart from urging members to contribute funds, is to inculcate pride in the prosperity of their spiritual home. Prosperity is certainly in evidence as a theme within this type of religiosity, but there is a different emphasis to this kind of prosperity than the individualistic, atomizing kind. In fact, the impression gathered there is 


\section{Thibaut Dubarry}

that it would be pointless to understand prosperity in only individualistic, consumerist categories.

One way in which the connection between Pentecostalism and the market could be regarded, is to first look beyond the market as metaphor, and rather consider how Pentecostal believers themselves understand the material world. Such an emic perspective might suggest that this is not merely a material world at all, but rather a Spirit imbued material world. A different way to describe this approach is the sacralization of materialism. Let us unpack this concept. Ngong's critique of the influential African theologian, Kwame Bediako provides a good point of introduction to this discussion, but for reasons other than what Ngong intends in his article. He is critical of Bediako's reliance on a so-called African worldview as fundamental to the African Christianity that he advocates theologically, which is a Christianity that grows and proliferates under conditions where a spirit world predominates in the here and now. To quote Ngong:

But [Bediako] does not see that this worldview has sometimes been very unhelpful to Africans. Examples of how this worldview may be unhelpful to Africans include the inordinate stress on the effect of spiritual beings on daily life and the view of daily life as a struggle for power. Because of the ubiquity of forces and powers that are usually seen as animating life, these forces and power are often blamed for evils that happen in society. This has nowhere been more serious than in witchcraft accusations where societies have been torn apart because of it (Ngong 2009:14).

Ngong therefore observes a blind spot in Bediako's treatment of the 'African worldview'. By 'uncritically' endorsing this worldview, Bediako disregards the fact that the African theology which he represents, relies on an African traditional religious/cultural view of salvation, where 'present material wellbeing appears to be ultimate in their understanding of salvation' (Ngong 2009:14). This, according to Ngong, is a different telos than that of the Christian tradition, and therefore this theological pursuit of Bediako's is premised on a wrong turning. One might in effect suggest that Ngong portrays Bediako as sacralizing the African traditional religious worldview by giving such high value to it. Bediako goes in this direction because of his understanding that Christianity has grown exponentially in sub-Saharan Africa under these very 
conditions. In other words, the growth of the Christianity that Bediako prefers is dependent on keeping this worldview intact. For Ngong this is theologycally problematic. However, if we take an empirical look at the situation, then Bediako's assessment, whatever its theological merits or demerits, seems to lend support to a basic idea posited here. African Christianity as exhibited in neo-Pentecostalism has its strength precisely because this 'African worldview', or perhaps more concretely the pull of indigenous African religions, remains influential. This suggests further that Christianity under these conditions may at least be complicit in the sacralization of the material world, if not necessarily materialism as such.

The specific link between Pentecostalism and the sacralization of materialism, even if not in those exact words have, however, been made by other authors. The title of an essay by Elsie Lewison is quite suggestive, reading as follows: Pentecostal power and the Holy Spirit of capitalism: Reimagining modernity in the charismatic cosmology (Lewison 2011). Referring to her data on Pentecostals in East Africa, Lewison paints a picture of a belief system that is premised on material advance in the Name of God, regarding which she comments: 'This revealed understanding of success bears distinct similarities to capitalist imagery, which portrays entrepreneurial insight as the sacred bearer of progress and growth' (Lewison 2011:43).

\section{Pentecostalism, Guilt-Tripping, and Capitalism}

Over the last several years, an identifiable trend among South Africa's bornfree generation has been a disillusionment with the 'rainbow nation', which was a popular designation for South Africa in the early years of its democracy. A second particularity of this generation is their adhesion to capitalism.

Pentecostal worshipers are at the opposite end of the spectrum of traditional Catholicism, where the collective (un)consciousness is dominated by a kind of social prejudice that stigmatizes and condemns wealth as part of a symptom of immorality, and adversely sacralizes the external sign of poverty. In older forms of Christianity, there is typically, theologically, a distinction between temporal and spiritual spheres. 'Render unto Caesar' is thus the beginning of a phrase attributed to Jesus in the synoptic Gospel: 'Render unto Caesar the things that are Caesar's, and unto God the things that are 


\section{Thibaut Dubarry}

God's' (Mt 22:21), or as it has also been expressed: 'Let every person be in subjection to the governing authorities. For there is no authority except from God and those which exist are established by God' (Rm 13:1). This fission creates, both originally and subsequently, a division between the political authority of Caesar and the religious authority placed under the auspices of God. However, in the kingdom of Caesar, it seems that it is presently the empire of Croesus which reigns, symbolically, in reference to the global and frequently ostentatious success of capitalism in the contemporary world. In Catholicism there might be a tendency to blame capitalism on the whole, to some extent as a sin since the church doctrine generally condemns wealth such as the Gospel of Matthew states: 'And again I say unto you, It is easier for a camel to go through the eye of a needle, than for a rich man to enter into the kingdom of God' (Mt 19:24). As stated above, this can consequently stigmatize well-off people.

Without any apparent shame, AFM and RFM believers demonstrate their materialistic success with, for instance, new luxurious cars. With these they visit their churches in Kayamandi, not embarrassed, but triumphantly, in order to demonstrate the saving power of the religious community and the grateful energy of theology which enable them to express their consumerist achievements under the holy seal of capitalism. Thus, Baba a 35-year-old Zimbabwean man confessed: 'Yes I am proud of myself. Thanks to the Lord, since I arrived in Cape Town from my native Zimbabwe, I was deprived of everything, I moved up the ladder. If I am a great businessmen it is thanks to the paramount role of God who incited me to become a successful company director. I am very proud of my success story, and I want to confirm to the youth who are a bit too pessimistic and excessively defeatists that we can be victorious of everything on the condition that we equip ourselves with the resources to support our ambitions and to deeply believe in God. I want to set an example. It is also my duty as a fervent believer' (Interview with Baba: May 6, 2018).

Walter Benjamin explains that capitalism can be considered as a religion. First, it 'essentially serves to satisfy the same worries, anguish, and disquiet' (Benjamin 1996:23). Second, 'this concretisation of the cult connects with a second characteristic of capitalism: the permanent duration of the cult' (Benjamin 1996:24). The third singularity of this cult holds that it 'engenders blame' (Benjamin 1996:25). The reason for this is that 'capitalism 
is presumably the first case of a blaming, rather than a repenting cult' (Benjamin 1996:26). For Benjamin, capitalism makes its followers guilty.

We could refer to the German concept of Schuld as analyzed by Friedrich Nietzsche, signifying etymologically, both debt and culpability. It is a mistake to translate this into 'fault'. We cannot distinguish in the religious system of capitalism between 'mythic culpability' and economic debt. Poor people in this perspective are guilty in that they fail to capitalize. For Benjamin, the specificity of atheist materialist religion does not provide an atoning rite. It provides neither a redemption nor a deletion of debt. Pentecostalism has its singular virtue in that it neither condemns material success, nor jeers well-off people. In religious language, the Pentecostal faith released worshipers from the demons of the culpability possibly induced by economic success. Such demons often haunt other religious forms, especially Catholicism.

\section{The Benediction of Material Success: Pentecostalism against Marx?}

Nietzsche announced perhaps prophetically in Dawn (Nietzsche 2011:65) that what was 'once done' for the love of God 'is now done for the love of money i.e., for the love of that which at present affords us the highest feeling of power and a good conscience'. Pentecostal churches illustrate this enchanted materialistic trend. On a Sunday morning, Pastor Russel (RFM) arrives triumphantly in a shining new BMW. He personally owns five cars used for Uber transportation services. Sometimes he provides a temporary job to one of his needy parishioners. He personifies a symbol of capitalistic success in spite of his modest Zimbabwean origins, since his life illustrates an upward trajectory of a self-made man. His three main passions are reportedly 'German cars, computer software, and God' (Interview with Pastor Russel: June 2019). He is a software developer in Cape Town.

Durkheim opined that 'god and society are one and the same' (Durkheim 1965:236). Hence, when one considers the way in which Russel would frame God, as part of a triad that includes products of consumerism and new technology, from the perspective of Durkheim it would make complete sense, because the sacralization of the material is logical, and commensurate with the Pentecostal reality. 


\section{Thibaut Dubarry}

Marx analyzed religion 'as a symptom and not the disease, [and] as a source of solace [that would not disappear] until the sources of people's pain - an unfair economic system - had been eradicated' (Marx 2014:65.) Marx focused on the link between religion and deprivation which originally stems from social class relations. Deprivation is essentially an economic phenomenon. Marx conceived religion as a reflection of a society in which individuals regard themselves as chiefly determined rather than determining actors. They project onto a supernatural realm in an elevated and exaggerated form. Besides, from a generalized approach, religion for Marx proves to be an expression of alienation in class-divided societies. Religion appears as both a tool for the manipulation and oppression of the subordinate class in society and, simultaneously, an expression of resignation and consolation (Marx 2014). That is why, in Marx's famous words, religion is 'the opium of the people' (Marx 2014:90). Theologically, from the beginning, religion makes a promise, constituting hope of a better future in heaven or some equivalent supernatural realm. Marx thus thought that all religions were opiate-like and that they were bound to engender apathy and impede any political improvement.

The link between economic deprivation and Pentecostalism has been well established, particularly in the 1970s and 1980s. This perspective still continues to enlighten global success, especially in Third World countries (Cox 2001; Martin 1990). Pentecostalism appears, in this way, as a metamorphosis of Christianity which contributes to enable impoverished masses and excluded individuals to satisfy their needs in a context of increasing inequalities and persistent discriminations. The community structure also provides them with opportunities to have access in the market. It participates moreover to grant psychological and usually, practical help to those people on the fringes of society, who frequently suffer from relative deprivation.

The religious communities hence bring mutual support, emotional release, and help them to create a sense of commonality. To use Hollenweger's expression, they represent 'islands of humanity' (Hollenweger 1972:457). This is all the more true in the South African context of the marginalities of the churches here studied, since segregation and anomy (Durkheim) reigns, eroding legal norms and constantly endangering the legitimacy of traditional values. Do we conclude that Marx was wrong regarding religion? Does Pentecostalism invalidate his whole thought? We 
should highlight that Marxism can partly explain the Pentecostal formation. Pentecostalism is, in Marxist terminology, a superstructure (Marx 2014:98).

For Marx, the societal superstructure rests upon production relations, i.e., class relationships. The superstructure is never an autonomous entity. It follows class developments and the conflicts therein. Marx called the 'base' the relations of economic production. It is how we work and produce together, to meet our social needs. Under capitalism, the relations of production are based upon an antagonism between those who sell their labor and those who own the means of production. These relations, Marx argues, form the 'base' of society, as it determines how we interact with each other day-today, as we produce. This base then influences the 'superstructure', defined by Marx as a broad coalition of everything from the state to arts and sciences, and of course, religion (Marx 2014:99). If we act in a certain way to each other during production, this will create a tendency for such relations to be reproduced in our cultural interactions.

Marx thus described religion as having a 'dual nature' in society. In The German ideology, he established a difference between the religion of the oppressed and the religion of the oppressor (Marx \& Engels 1972). When examining the social make-up of the orthodox churches in the $19^{\text {th }}$-century Europe, Marx remarked that while these institutions were hoarding large quantities of wealth and land, the pious people were themselves deeply impoverished. During periods of social unrest, these two opposing class forces, despite belonging to the same religion, would find themselves in direct confrontation. In the revolutions of 1848 across Europe, the Catholic and Orthodox churches used their stature to support their respective states, while large sections of devout Christian peasants violently fought against them. This shows that, as a result of the social make-up of the church being crossclass, religion can in practice play both a reactionary and a progressive role in moments of social unrest. Marx asserted that religion has a psychological function. He called it 'the heart of a heartless world' (Marx 2014:103). Religion could humanize a world made inhuman by exploitation. Pentecostalism can be analyzed in light of Marxism, since it appears as a religion of the 'base'. Its main singularity holds in the fact that in contrast to Catholicism, it does not make an exclusive eschatological promise and it does not condemn wealth on earth. However, we can perceive how the material world shapes its content. For this reason, we could qualify it as a religion of the capital. 


\section{Thibaut Dubarry}

Pentecostal institutions are extremely effective in bringing about dramatic changes in subjectivity. Numerous scholars are underlining this tendency, dubbing it a 'revision of consciousness' (Martin 1990:287), a 'remaking of the individual' (Maxwell 1998:352), or a 'reorientation of persons' (Barbalet 2008:75). We should note a salient point, although less noticed, by underscoring the congruence between the re-formed Pentecostal subjectivity and the neoliberal one required to succeed in the contemporary capitalist economy (Comaroff \& Comaroff 2000; Maxwell 2005).

\section{Pentecostal Salvation in the Eternity of the Present}

It has frequently been observed that the ethos of Protestantism might inflict austerity among its adherents. We can probably explain that, principally by the notion that they are supposedly under the thrall of predestination (Buis 2007). There are different Protestant beliefs regarding this dogma (Lange 2005). Lutheranism and Calvinism share the notion of unconditional election with varying interpretations of how it relates to individuals (Peterson \& Williams 2010:98). As for Arminianism, conditional election is in view of foreseen faith or unbelief.

In the case of Pentecostalism, salvation is in the hand of each worshiper and accomplishes itself primarily within the community and, by extension, in the socio-economic sphere. From this singular theological perspective, the future is embedded in the present. The past fades away for the profit of a creative instant. We should emphasize that during the sermons we listened to, pastors did not deal with the wounds of the past. They constantly exhorted their parishioners to be conscious that they are the unique authors of their destinies and taught them not to complain about their possible past mistakes. The objective injustices created by neoliberal policies must be subjectively combated. The difficulties met must be considered as trial-byordeal and as a self-battle with the objective of release from various traps they have to face.

One of the most stunning observations we made during our ethnographies is the evident joy which irradiated a large majority of believers' faces. If precariousness and crime could dent their confidence in the future, it seems, in contrast, that believers are extremely optimistic regarding their destinies. Their faith procures them a latent promise that, with 


\section{Pentecostal Churches and Capitalism in a South African Township}

the prerequisite that they trust God and adhere actively to their religious community, everything becomes possible. Eschatology is no longer situated after a future divine judgment, but in the very immanence of their community and society. There is also an ontological continuity between spiritual and temporal spheres. Presentism is the rule. From this view, neither the future nor the past exists. We observed, through Pentecostal communal activities, what we could qualify as the eternity of the present. Indeed, we observed a kind of syncretism between faith and entertainment. For instance, every month Pastor Russel arranges a weekend away at a camp site for his congregation. He has also organized what he calls a 'funny dressing competition' for all members of his church. Each parishioner had to be disguised.

Weber refers to the 'theodicy of disprivilege' (Weber 1993), the belief of the promise that salvation may be granted as a reward for earthly poverty. He theoretically posits that religion is rationally motivated by 'the rules of experience' and therefore should not be apart from the range of everyday conduct, 'particularly since even the ends of the religious and magical actions are predominantly economic' (Weber 1993:1). One cannot but recognize that Pentecostalism makes, in contrast to Catholicism, a promise of a temporal reward. Thus, material success justifies religious adhesion. The adhesion to the Pentecostal promise justifies a faith which is rewarded on earth and not in a hypothetical future.

Furthermore, the religious officials had often greatly become enriched by virtue of the power of the Holy Spirit, reinforcing, accordingly their legitimacies since they personally symbolize that the faith corresponds to what Austin names 'performative' (Austin 1975:29). In this perspective, belief is not just a devout attitude, then reducible to its abstract, or even an illusory dimension. It contains, in itself, a so-called 'performative utterance', reason for which 'to believe is to do' from our Wittgenstein reading. The belief also has a virtuous power, especially in the economic field. The investment in the community legitimates, as a result, the faith, representing what we could conceptualize as a theodicy of success and privilege. The theology of prosperity is consequently justified.

In the following sections we will argue that Pentecostal churches appear as a hybridity of liberal democracy and communism, projecting themselves on a 'salvation market'. 


\section{Thibaut Dubarry}

\section{Pentecostalism as a Secular Religion}

Paradoxically, we can argue that Pentecostal faith reflects the process of secularization. We should highlight first, that this dynamic is both very ambivalent and controversial: 'The seminal thinkers of the nineteenth century Auguste Comte, Herbert Spencer, Emile Durkheim, Max Weber, Karl Marx, and Sigmund Freud - all believed that religion would gradually fade in importance and cease to be significant with the advent of industrial Society' (Inglehart \& Norris 2011:1). Inglehart and Norris, however, give further nuance to the secularization theory which 'is currently experiencing the most sustained challenge in its long history’ (Inglehart \& Norris 2011:54). First, Peter Berger, once a strong advocate for secularization (Berger 1967), recanted his earlier claims: 'The world today, with some exceptions...is as furiously religious as it ever was, and in some places more so than ever. This means that a whole body of literature by historians and social scientists loosely labelled "secularization theory" is essentially mistaken' (Berger 1999:2). Similarly, Rodney Stark and Roger Finke explain that, 'after nearly three centuries of utterly failed prophecies and misrepresentations of both present and past, it seems time to carry the secularization doctrine to the graveyard of failed theories, and there to whisper "requiescat in pace" (rest in peace) (Stark \& Finke 2000:79).

Karl Löwith's work defends the thesis that Christian eschatology became transformed into the philosophies of history of the Enlightenment and, ultimately, begat the ideology of communism (Löwith 2011). In this respect, Pentecostal salvation appears as a continuum with the communist ideology. Its eschatology likewise realizes itself on earth within the immanence of the market.

Blumenberg prefers to speak in terms of 'reconfiguration' (Umbesetzung) rather than of 'conversion' (Umsetzung) of inherited concepts (Blumenberg 1985:90). He resists the idea of a 'cultural debt' that modernity supposedly has to discharge to its religious past. The opening section of The legitimacy of the modern age (Blumenberg 1985:95) is thus comprised of a critique of one of the foremost categories for the depreciation of modernity, namely the notion of secularization, or more precisely what Blumenberg calls the 'secularization theorem' (Blumenberg 1985:97). It may be expressed according to the famous formula inspired by Schmitt's Political theology: '[A]ll significant concepts of the modern theory of the state are secularized 
theological concepts' (Schmitt 1985:78). Thus, the state appears in this logic, as a secularization of the church. In a context of neoliberal policies, where the government fails to regulate society, we observe, according to Michel de Certeau's expression, that 'the religious comes back when politics fail' (De Certeau \& Giard 1987:93). Consequently, Pentecostal pastors can have a function, to some extent, of governance within the community when the traditional political institution fails to rule South African urban marginalities. This is one of the principal reasons why countless churches are very successful in townships, since they can, even partly, remedy the insufficiencies of the South African state institutions.

We should analyze the dialectic between Pentecostalism and capitalism by undertaking a philosophical and psychoanalytic anthropology of the theological economy of capitalism. We can assimilate in this perspective the modern representation of sovereignty, defined since Jean Bodin, as absolute power, to a transposition of the potentia absoluta Dei (the absolute power of God) (Bodin 1992:65). Against this rationalistic and liberal modernity, Schmitt (2008a) employs the resources supplied by the 'secularization theorem' and in particular, those linked to the idea of myth. The focus is on Schmitt's notion of constitution-making power (verfassunggebende Gewalt) as it is formulated in his work Constitutional theory (Schmitt 2008a:121). Schmitt argues that in a modern democracy, the constitution-making power of the people (Volk) is analogical to God's potestas constituens (power of constituents) in medieval theology. From a Schmittian perspective, this means that the constitution-making power would also be a secularized theological notion.

The main difference of opinion concerns the meaning of modern sovereignty. In Blumenberg's perspective, the question is not so much the substitution of the absolute power of man for that of God. Less than transposing a model, the significant issue holds in the problem of abandoning the question of authority, through the switch of autocracy with the impersonal power of reason. The notion of sovereignty contains in its core a theological dimension. It has been used as a 'cover' for liberating oneself from the theocratic schema. We thus argue that the potentia absoluta Dei has been transferred and secularized to what we could conceptualize under the category of a monotheism of the market in a global neoliberal context of the weakening of the state, which also typifies South Africa. The market thus appears as a secularization of the divine omnipotence. Henceforth the 


\section{Thibaut Dubarry}

sovereignty is principally economic. We switched from a community of believers living under the aegis of the potentia absoluta Dei to a society of consumers, organized under the thumb of the potentia absoluta (absolute power) - the divinized law of capitalism which now governs the market.

The magisterial work of the philosopher, Charles Taylor has done much to bring greater nuance in scholarly discourse on the relation between religion and secularization over time. In A secular age, Taylor is 'telling a story...of "secularization" in the modern West' (Taylor 2007:ix), and what the process amounts to with respect to religion, which is treated 'as that which is retreating in public space (1), or as a type of belief and practice which is or is not in regression (2), and as a certain kind of belief or commitment whose conditions in this age are being examined (3)' (Taylor 2007:15). Taylor's work is primarily concerned with developments in the modern West, and also in an age of globalization that affects the contemporary South Africa as much as any other place. His work also has much relevance for Pentecostalism, that is if this type of religiosity is understood as falling under Taylor's abovementioned mode two, which allows for religion possibly being, but also possibly not being in regression.

The secular sovereignty of capitalism fits remarkably well with the Pentecostal spirit. This is perhaps part of the irony of the age in which we live, wherein despite the profound impact of secularization, many spaces in urban Africa, such as Kayamandi, experience a blossoming of a form of religiosity that is supremely adapted to the secular and the material. This seems strange if one thinks that Western patterns of secularization should apply everywhere. Taylor himself does not think so, but he is clear that the secular itself, historically speaking, is part of a dyad emerging out of the Western Christendom, the other being the sacred (Taylor 2007:98). Originally, the emergence of the secular referred to time and the question of who regulated it. Hence, the church's time as expressed in the activities of monastic orders, for example, was sacred, but secular time was beyond their control. Eventually these came to refer to other aspects of life, but still maintaining the basic binary of secular and sacred.

This process, of course, occurred in Africa through colonial incursion, and only with varying degrees of success. As an indigenous or at least highly adapted and thus indigenized form of religiosity, Pentecostalism, due to its socio-geographical location in Africa, might not be much affected by the consequences of this classic dyad. If that is the case, it might partly 
explain why a supposedly secular sovereign such as post-industrial capitalism could be all but Christianized within many Pentecostal communities. In addition to challenging our notions of the secular, it prompts a re-examination of religion and its role in society.

Churches such as the AFM and RFM can be interpreted on one level as compensating for the numerous lacks of the South African welfare system. Since the beginning of the 1990s, an array of neoliberal policies (cf. Bond 2000) has exacerbated the various deficiencies of the nation state. Religious institutions attempt to fill the void.

\section{The Salvation Market}

What we observed in Kayamandi is the furious competition between various religious institutions (AFM and RFM, of course, and also Anglican, Presbyterian, Methodist, etc.) which operate through what we could call a 'salvation market'. There is one market in the sense that there is a confrontation, at the township scale, between the supply of diverse churches and the demand of multiple potential believers. Official members, affiliated to the constellation of Pentecostal communities, must actively try to recruit new believers in their own social circles and surroundings of the church, while convincing those targeted that their religious community is the best to improve their lives. They consequently explain, for instance, that their own pastor is more charismatic than others, as asserted to us by a young AFM worshiper.

At the beginning of every AFM worship service, the pastor asks the first timers to stand up. Then he proposes that every new participant can become either just a 'visitor', an 'official member' of the church, or someone who needs 'to be saved'. They consequently have to complete a form in which they must put their choice in this regard, as well as their personal information. At for RFM church, Pastor Russel is quite a frenetic user of WhatsApp. This corresponds to a worldwide trend of mobilizing new technologies by many Pentecostal churches such as, for example, in Nigeria and Ghana (Hackett 1998). These movements are indeed increasingly making use of electronic media as suitable sites for their preaching and extending their 'empires of faith'. This cross-platform's instant messaging service for smartphones enables him to constitute a 'social capital' such as theorized by Bourdieu (1986). It also corresponds to the aggregate of the actual or 


\section{Thibaut Dubarry}

potential resources which are linked to the possession of a durable network of more or less institutionalized relations of mutual acquaintance and recognition. Every morning, he sends an evangelistic message to all his members, commenting on some chosen extracts of scripture and demanding that each worshiper reaffirms that they believe in God, by finally texting something like 'Alleluia' or 'The Lord is with me'.

Here follows an example of a WhatsApp message from Pastor Russel on November 15, 2015, at 6:53 AM: 'One of the greatest stories in the Gospels is of Jesus healing a woman bowed over with a spirit of infirmity for 18 years. Imagine never being able to see the sky or rainbows, but only the dust of the earth and the grubby feet of people - what a painful existence she lived! I love how Jesus saw her and immediately called her over to receive a miracle from Him. The woman had been bound in this condition for 18 years, a number which represents bondage in the Bible. When Jesus said to her, "Woman, you are loosed from your infirmity", He was proclaiming liberty over her and setting her free from the bondage of the devil. He laid hands on her and she immediately received her healing. Today, you have already been set free from the curse of sickness by Jesus' one perfect sacrifice at the cross. Believe it and proclaim your liberty won by His finished work!' (Russel 2015).

With this comment, he sanctifies the message of Christ by a dual dynamic. First, he demonstrates the power of what theologians refer to as kenosis (Evans 2006:78). This theory states that Jesus gave up some of his divine attributes while he was a man here on earth. These three attributes were his omniscience, omnipresence, and omnipotence. Christ did this voluntarily so that he could function as a man in order to fulfil the work of redemption. It consecutively divinizes individuals and consecrates mankind, to some extent to a communist community in that all members are ontologically creatures of God, without distinction of chiefly gender, race, and socioeconomic status. As a result, they shared, equally and universally, common values around God within humanity as an extensive community. He also expressed how relevant the gospel is for the daily life of his believers, expressing a selflegitimating prophecy. 


\section{The Market as God}

From a Pentecostal perspective, the market seems to be the new place, which has been sacralized to reach equality, or perhaps temporal salvation. This implies a paradox, which is that the new transcendence is, hereafter, a vertical ascension within quite a restrictive immanent and horizontal enchanted materialism, which can, however, produce and even exacerbate factual inequalities. In reality, it corresponds more to an ontological equality. Theologically speaking, individuals are indeed potentially equal in terms of an economic elevation through the social ladder. With this in mind, the religious discourses of pastors, continually and consensually, encourage their members, as we observed, during our ethnographies at the AFM and RFM churches, to invest vigorously in business.

Numerous authors described, in the same vein, the market as God. Loy remarks that

the collapse of communism - best understood as a capitalist 'heresy' - makes it more apparent that the Market is becoming the first truly world religion, binding all corners of the globe more and more tightly into a worldview and set of values whose religious role we overlook only because we insist on seeing them as 'secular' (Loy 1997:89).

Harvey Cox notices, similarly and preliminary, that 'at the apex of any theological system, of course, is its doctrine of God' (Cox 2016:23). Thus 'in the new theology this celestial pinnacle is occupied by The Market'. Karl Polanyi has formerly demonstrated that, over the last two centuries, the Market 'has risen above these demigods and chthonic spirits to become First Cause' (Polanyi 1957:89). More recently, Beyer (2013) has drawn on the systems theory to show how, in global society, religion and markets are modelled on one another. It is necessary to recognize a 'theology of the market', in which this new secular eschatology positions itself by the rational and relative arbitrary law of supply and demand. Pentecostalism, following and intensifying evangelical Protestantism, emerges as the religion of the entry into capitalism as has already been described and highlighted in Latin America (García-Ruiz \& Michel 2012). 


\section{Thibaut Dubarry}

\section{The Religious Market and the Goods of Salvation}

The term 'salvation good' (Heilsgut) is central to the works of Weber (2013). The fact that this has gone unnoticed in the Anglo-Saxon world, is probably due to the awkwardness of the translations, 'state of salvation', 'substantively divine salvation', 'highest bliss available', or even 'sacred values' (Weber 2013:43). These different translations lose the sense which is relevant for us, namely, that Weber talks about 'goods' which can be striven for, supplied and consumed, instead of 'salvation goals' (Heilziele), 'salvation means' (Heilsmittel), and 'promises of the religions' (Verheissungen der Religionen) (Weber 2013:98).

In a widely cited article in the American Journal of Sociology, Stephen Warner (1993) argues that the sociology of religion has moved to a new 'paradigm': Rational choice. Scholars like Rodney Stark (cf. Stark \& Bainbridge 1996; Stark \& Finke 2000), William Bainbridge (cf. Stark \& Bainbridge 1996), Roger Finke (cf. Stark \& Finke 2000), and Laurence Iannaccone $(1991,1998)$ depict churches and sects as 'religious firms' that produce and sell 'religious goods' in a 'religious market' to satisfy the 'religious needs' of consumers. The community offers an 'opportunity structure' to get 'salvation goods'. The AFM church might be interpreted according to this religious paradigm where rationality rules so much that it can be projected into a strategic field where pastors determinately compete with each other, trying to gain some parts of this singular market by adapting the supply to the demand. There is therefore usually an English translator to reach new people because the pastor is a Xhosa native speaker. Yet a growing number of Zimbabweans who attend this worship speak only Shona and English, making Xhosa, an indigenous South African language, a linguistic obstacle to the conquest of a larger audience among new immigrants.

Another example of 'salvation good' is health. Look at the role of churches towards the HIV/AIDS epidemic. If pastors, throughout Africa, are still very ambivalent regarding the virus, we have observed that they no longer massively condemn seropositive people. The application of this theology of health as a good can have a virtuous 'autoimmune function' (Burchardt 2016:54), since it preaches the precondition that believers should moderate their sexuality, respect their partner, and be faithful. Here is why we could describe the belonging to the church as a "communalization of prevention'. In this regard, faith appears to possess a 'self-fulfilling 
legitimacy', in the vein of 'the self-fulfilling prophecy', defined by Merton in the sense of 'a false definition of the situation evoking a new behaviour which makes the original false conception come true' (Merton 1968:21). To believe is not just about a virtuous behavior for the sake of being virtuous. Faith is justified since it can hedge against sexual disease contaminations.

\section{Pentecostalism as a Combination of the two Secular Religions of the $20^{\text {th }}$ Century?}

The term 'Hegel's dialectics' refers to the particular dialectical method of argument employed by this $18^{\text {th }}$ - and $19^{\text {th }}$-century German philosopher, which relies on a contradictory process between opposing sides (Hegel 1998). In other words, it involves the reconciliation of ostensible paradoxes to arrive at absolute truth. The usual formulation of Hegel's dialectics is a three-step process comprising the movement from thesis to antithesis to synthesis. One begins with a static, clearly delineated concept (or thesis), then moves to its opposite (or antithesis), which represents any contradictions derived from a consideration of the rigidly defined thesis. The thesis and antithesis are yoked and resolved to form the embracing resolution - the synthesis.

We can relate this philosophical method to the $20^{\text {th }}$ century in which the Cold War occurred, which manifested itself as a bipolar order in which two blocks confronted each other: A Western world versus a communist one. This geopolitical and apparently secular antagonism can paradoxically be metaphorized as a 'war of religions' or, from a Hegelian approach, two components of his dialectics where the thesis is 'liberal democracy' and 'communism' the antithesis. Pentecostalism can also be interpreted as a synthesis between those two antagonist 'secular religions', i.e., the combination of the two. Pentecostalism is composed, first, of liberal democracy insofar its religious principles sanctify democratic ideals. This is indeed constitutive of a basic principle of equality on an individual basis. It is also shaped by a materialistic conception of humanity. Second, Pentecostalism is structured on a communistic common ground. Let us now first detail some of the ways in which Pentecostalism could be regarded as a child of liberal democracy.

De Tocqueville in Democracy in America (De Tocqueville 2013) has extensively developed the democratic American so-called 'passion for equality'. He explains and describes how equality is the founding principle of 


\section{Thibaut Dubarry}

democracy. He also demonstrates how this peculiar passion has spread ineluctably over the centuries, and the modes in which it came to affect all aspects of the social life of a democracy over time. This 'passion for equality' significantly animates the idiosyncratic religious body of Pentecostal communities by shaping their forms and structuring their content.

The philosopher, Marcel Gauchet (1999) theorizes that 'Christianity is the religion of the exit of religion'. He details a genealogy, in the form of a tetralogy (Gauchet 1999, 2013, 2014, 2017) in which he shows how Christianity gradually, ontologically, and theologically, engendered democracy. In his work he demonstrates how the creation of the modern world is based on substituting one type of foundation for another, moving from a transcendent, magical-theological foundation to a rational, immanent one (Gauchet 1999:98). According to this thesis, the world has also switched from being heteronomous to being autonomous. Liberal democracy is understood as the new anthropological structure which now frames most contemporary societies. Regarding Pentecostal lives, we noticed that what Weber refers to with the concept of 'polytheism of values', rules their destinies in that the worshipers have consecrated various sets of values. We should indicate more precisely that their values have been rationalized through the immanent community structure.

We come to the Nietzschean idea, that values become a matter of individual self-creation and self-cultivation. These religious rejections of the world follow what Weber termed a value rationality, a conscious orientation towards salvation, enacted through a commitment to ethical norms of a universal brotherhood in opposition to the 'possession of...things worldly' (Weber 2013:89). Weber explains that, in its respective spheres, values function as 'gods of the various orders', or 'godheads', which in its plurality must be considered a 'polytheism' (Weber 1958:148-149). Weber figures these ultimate values as warring gods: 'So long as life remains immanent and is interpreted in its own terms', he argues, 'it knows only of an unceasing struggle of these gods with one another' (Weber 2013152). 'This war becomes manifest as each sphere is increasingly rationalised, its value absolute, floating free of its enactments, irreducible to particular practices or maxims, on the one side, and the basis of an increasingly conscious and intense interior commitment, or inner faith, on the other side' (Weber 1958:328). 
Francis Fukuyama has published a famous article, then a book in 1992, The end of history and the last man (Fukuyama 1992). He expresses the original thesis that the great ideological battles between East and West were at an end in 1989 with the fall of the Berlin Wall. The Western capitalist, liberal democracy is considered as having undeniably triumphed which heralds, from a Hegelian perspective, inspired by Kojeve, the 'end of history'. This is the first part of Fukuyama's title. The second part is, albeit less analyzed, maybe the more relevant, since he interprets Nietzsche's social theory that culminates in the idea of 'the last man' as a theory of the decline of a certain thymos in the modern world. Fukuyama indeed distinguished two forms of thymos: megalothymia, or the desire to be treated as superior to other individuals, and isothymia, the desire to be considered equal to others.

This specific part of the soul is the seat of pride, that which makes human beings seek recognition from others, gives them courage and the need for prestige and honor, and makes it possible for them to defy the desire for self-preservation. By distinguishing megalothymia from isothymia, he clearly establishes a caesura instituted by liberal democracy which henceforth bases itself on isothymia. Hegel makes thymos, displayed in the 'dialectic of master and slave', the key dynamic in history (Hegel 1998:87). Fukuyama pursues the idea that megalothymia is striving 'to be recognized as superior', which dominates in aristocratic warrior societies, given that it denotes the field of pride, honor, distinction, and recognition (Hegel 1998:103). This inspired the citizens of the Greek poleis and was central in all warrior ethics. It is the opposite from isothymia, as having an intrinsic worth or dignity. This latter form of thymos is linked to the advent of a modern capitalist democracy. Pentecostal believers are inspired by a capitalistic ethos, corresponding to the desire of equality.

Although being situated within an undeniably patriarchal culture, more recent expressions of Pentecostalism may be moving towards a type of 'gender democracy' in so far as males and females, on the condition that they belong to the community, are theologically considered as irreversibly and irrefutably equal. During our ethnographies we observed that, in AFM and RFM churches, worshipers are randomly disseminated in the room with no division regarding seating arrangements or other types of separation along gender lines. This is quite different from some other African churches. The Zion Christian Church (ZCC), for example, has strict rules of where men and women are supposed to sit in church. There are even different doors through 


\section{Thibaut Dubarry}

which men and women enter and leave a church building (cf. Müller 2011:36). The ZCC is overall much more patriarchal compared to either the AFM or the RFM. The ZCC is perhaps more reflective of a traditional African society, whereas these newer Pentecostal groups as well as urban centered churches like the AFM have a different ethos. There was an equalizing tendency perceived in our experiences, particularly with the AFM. There we could easily have discussions with clerical authorities at the end of a worship service. This is also different from the ZCC where it is much more difficult to initiate conversations with higher-ups in the church hierarchy. By contrast, the AFM and the RFM do not exhibit a stark human pyramid which structures individuals, measured by their importance in function of their religious status.

Another illustration of this ambiguous process of democratization of holiness is the glossolalia phenomenon, which implies that any believer can 'speak in tongues' during the communal worship, without distinction of status. Hence, speaking the word of God is not the monopoly of a religious elite. The 'Spirit of God' does not need any privileged intercessor, as Cox likewise concluded (Cox 2001:87). Pentecostal believers can then appropriate for themselves a holiness of faith within the community. That is why we can justify the case that Pentecostalism is expresses as a form of communism.

Troeltsch (Sozial Lehre) explains that the 'primitive Christian experience' was characterized by a type of communism, a so-called 'communism of love...It was a communism constituted only of consumers, a communism funded on the postulate that members could earn their lives through private enterprises in order to make themselves capable to practice generosity and sacrifice' (Troeltsch 2018:97). With regards to Pentecostalism, we suggest a switch in terms of values. The market appears as a partial substitute for love.

Weber inaugurates the terms 'communal relationships' (Vergemeinschaftung) and 'communization' (Vergesellschaftung) (Weber 2013:23). He was, among other things, alluding to Ferdinand Tönnies' well-known usage of 'community' (Gemeinschaft) and 'society' (Gesellschaft) (Tönnies 1957: 98), as well as to related conceptions in the work of Georg Simmel and Kurt Wolff (1964). Weber analyzes societal action (Gesellschaftshandeln) and communal action (Vergesellschaftungshandeln) as both phenomenal forms of social action (Gemeinschaftshandeln), 'meaningfully related to the behaviour of other persons' (Weber 2013:52). That is why he made use of the concept 
of Gemeinschaft as a general concept for quite varied social groups and formations (Weber 2010).

Weber illustrates his thesis by the example of, first, the family, second, the ethnic and political community, then, the religious community and, lastly, analogically, the market community. He distinguishes, thereafter, like Simmel, between occasional ('ephemeral') and enduring ('perennial') forms of association (Vergesellschaftung) (Weber 2013:98). In his 1913 essay, he introduces, as an example of the existence of a consensus community (Einverständnis-Vergemeinschaftung), among other forms, a market community (Marktgemeinschaft) or 'community of the market' and a linguistic community (Sprachgemeinschaft) (Weber 2013:45).

We should emphasize that Weber refers to it as a communal relationship (Vergemeinschaftung), 'based on a subjective feeling of the parties, whether affectual or traditional, that they belong together' (Weber 2013:40). The main reason may be that the market is reported as one of the most rational conceivable forms of the reconciliation of interests. It represents logically a community of interests. Weber justifies his argument by explaining further that the use of money is principally oriented to the expectation that even future participants in a market will accept money. However, this involves no orientation to concretize a rules based order, specifying the form in which the needs of those involved will be met. It is in the interest of individual market participants that other participants behave just as rationally as they do themselves. We observe, through the Pentecostal ethos, what we could qualify as a spiritualization of capitalism and consecutively a sacralization of the market.

The French writer, André Malraux purportedly stated in 1965, that Islam would be the communism of the $21^{\text {st }}$ century, justifying his claim by arguing that the contemporary emergence of Islam was comparable to the advent of the soviet regime, back then in the Russian society (cf. Delpuech \& Séguin 1996:89). We underpin the thesis that it is, in reality, more judiciously Pentecostalism which can be assimilated to the new communism of our time. Raymond Aron (2001:54) asserts that communism was a 'secular religion'. Communism and Nazism are reported as two false ideologies. Inspired by Freud, it refers to the future of an illusion, which portrays religion as outdated (Freud 2012). Freud singled out nationalism as a quasi-religious illusion: 'One may describe as an illusion the assertion made by certain nationalists that the Indo-Germanic race is the only one capable of civilization' (Freud 


\section{Thibaut Dubarry}

2012:89). Aron proposes "to call "secular religions" the doctrines that situate, in this world, in the future horizon, in a social order to be created, the salvation of humanity' (Casanova 1985:370). Older religions were not able to elicit a belief in an age of science (Casanova 1985:376).

In a context of disenchantment, dereliction can appear as an ineluctable source of despair: 'That people may live without believing in the afterlife is certain...Yet, if man can do without God, it is doubtful he can live without hope' (Casanova 1985:376). Communism, as a secular religion, was able to offer a substitute for the unifying power of ancient religion: 'The accumulation of dispersed knowledge, ever more overwhelming, redoubles the wish for a system' (Casanova 1985:377). Secular religions 'restore a supreme principle of authority at a time when all others are breaking down' (Casanova 1985:377). Pentecostalism is capable, henceforth of fulfilling this function when other traditional religions, including Catholicism and mainstream Protestantism see their influence waning ineluctably throughout many contemporary societies.

For the Islamic scholar, Maxime Rodinson (1978), the Muslim faith 'is communism with God', which means that the commonality between the two holds in mass proselytism and social control of each believer.

We could further describe Pentecostalism within the perspective of 'neoliberal governmentality' (Burchardt 2017:67). Foucault analyzes it primarily as the contact point between technologies of power and technologies of the self (Luther, Gutman, \& Hutton 1988:19). It consecutively refers to practices that govern human behavior through forms of address, which determine subjectivities and identities. We observed what might be called 'pastorpreneurs', in that Pentecostal leaders govern their communities as genuine enterprises. Pastor Russel (RFM) insisted particularly, during our interview with him, that his main vocation aims at reaching what he calls, 'empowerment'. The members of his holy institution must thereby achieve their belief by respecting, not so much an ethereal and spiritual horizon, but a 'temporal ideal' of accomplishment, while creating companies in any kind of economic sector. He emphasizes such points during recurring and passionate preaching. His religious discourse is characterized by a lexical field, rooted mainly in temporal and materialistic spheres, for example, faith is equated to an 'investment'. He constantly valorizes 'competition', he persistently promotes 'entrepreneurship's values', and he continually sanctifies 'business meritocracy'. 


\section{Pentecostal Churches and Capitalism in a South African Township}

If we want to achieve our connection with Islam as a form of communism, we should finally refer to the prominent specialist, Louis Massignon who explains that this religion corresponds, a bit differently, yet slightly analogously, to an 'egalitarian and lay theocracy' (Massignon 1922: 719): It signifies, first, that 'all worshipers are brothers' and, second, that 'there is no clergy'. In Pentecostal churches there is a strong solidarity between members. Equality seals their relations which might be more akin or related to the original rule of Christian communities. There is, in reality, a clergy that presides over them. However, there is no strong hierarchy such as exhibited by Catholicism with a precedence of priests over the masses. We have even encountered women among the pastors at the AFM, although this is still more exceptional than normal.

\section{Conclusion}

Following our ethnographies and in an attempt to bring the discussion to an end, we should conclude by synthesizing our thesis that Pentecostalism intrinsically reveals itself as a material, secular, and egalitarian theocracy and constitutes, as a result, what we conceptualize as communism of the market, representing perhaps, 'the religion of the end of religion'. Our contemporary world has undeniably sacralized the realm of capitalism. This religious trend corresponds, from the outset, to a material, secular, and egalitarian theocracy. By this expression, we want to bring to light that Pentecostalism is crossinfused and profoundly filled by materialism. It is indeed what we could denote as a religion of the capital and communism of the market. It is rooted in a deeply secular process, which is particularly ambivalent and relatively paradoxical. Besides, it is shaped by individualistic democratic ideals, since real equality seems to be an impassable horizon at a collective scale.

In light of the above, we qualify Pentecostalism as a 'religion of the end of religion'. It means that traditional features of religion strain to disappear with this specific religious trend. First, the classical distinction between holiness and profane tends to faint away. More precisely, there is a fusion between the two. The sacredness of yesteryear has been transferred, in that respect, toward the world which was previously trenchantly despised, first and foremost, by Catholicism. Second, eschatology is theologically reconfigured so that the promise of the last judgment vanishes for the benefit 


\section{Thibaut Dubarry}

of the very immanent arbitrariness of laws of supply and demand, which are now governed by a sacralized market. Third, the believers can be compared to new consumers using up salvation goods, produced by entrepreneurs of faith who are the pastors of these churches, and who make use of diverse strategies to gain some part in this singular salvation market.

That is why Pentecostal churches in townships illustrate and reflect, however paradoxically, this modern and ambivalent dynamic of apparently simultaneous religious disenchantment and a consecration of capitalism. Put differently, they reenchant societies in a context of secularization. Disenchantment (Entzauberung) in the Weberian lexicology, is indeed the complex cultural rationalization and devaluation of mysticism, which infuse, since the end of the $19^{\text {th }}$ century, much of the Western modernity. Now we have a situation of re-enchantment and salvation enabled, principally, through holy capitalism, where material success is both worshiped and facilitated by individuals' proportional involvement in community life. Religious institutions organize, consecutively, rationally, albeit maybe unconsciously, a communalization of believers' interests and demands.

For these reasons, Pentecostal churches in South African townships can be likened to small-scale communist organizations with the principal paradox, that it is a capitalist structure, as 'the base', in the Marxist terminology, which dramatically shapes its 'superstructure'. The latter is necessarily determined by the materialistic ethos which stems from the base. Racially segregated townships containing the lingering stigma of apartheid, have been entrenched by recent neoliberal policies, exacerbating the capitalist dynamic even in the religious sphere. The worshipers seem to aspire to the unique and contradictory verticality of the immanence of the market. It appears then that they are no longer elevated by the pure transcendental hope of a future eschatology. Instead, soteriology emerges - and deploys - through the sole social and reciprocal horizontality of the community, and by extension, in the economic field, crystalized by the market, which is the contemporary privileged and divinized space to reach this salvation. However, if this economic space can be relevantly imagined as a new 'secular paradise', it could also radically and inversely metamorphose into an authentic hell hic et nunc if you live at the margins of it. Whatever salvation realizes itself thus, is eventually, mainly a consequence and by means of inner-worldly asceticism, construed in the sacredness now residing in the values of entrepreneurship and via the business praxis. Such salvation is both contradictory and com- 
plementary of compulsive consumerism. Ultimately, it accomplishes itself on behalf of a capitalistic ideal, what Nietzsche (2000:87) tragically characterizes as resonating with an 'earthly consonance'.

\section{References}

Anderson, A.H. 2004. An introduction to Pentecostalism: Global charismatic Christianity. Cambridge: Cambridge University Press.

Aron, R. 2001. The opium of the intellectuals. New Brunswick: Transaction Publishers.

Attanasi, K. \& A Yong (eds.) 2012. Under the radar: Pentecostalism in South Africa and its potential social and economic role. Christianities of the world. New York: Palgrave Macmillan. doi: https://doi.org/ 10.1057/9781137011169_4.

Austin, J.L. 1975. How to do things with words. Oxford: Oxford University Press.

Barbalet, J. 2008. Weber, passion and profits: 'The Protestant ethic and the spirit of capitalism' in context. Cambridge: Cambridge University Press. doi: 10.1017/CBO9780511488757.

Benjamin, W. 1996. Selected writings 1: 1913-1926. Harvard: Harvard University Press.

Berger, P.L. 1967. The sacred canopy. Garden City: Anchor.

Berger, P.L. (ed.) 1999. The desecularization of the world: Resurgent religion and world politics. Grand Rapids: William B. Eerdmans.

Beyer, P. 2013. Questioning the secular/religious divide in a postWestphalian world. International Sociology 28, 6: 663-679.

Blumenberg, H. 1985. The legitimacy of the modern age. Cambridge: MIT Press.

Bodin, J. 1992. Bodin: On sovereignty. Cambridge: Cambridge University Press.

Bond, P. 2000. Elite transition: From apartheid to Neoliberalism in South Africa. London: Pluto Press.

Bourdieu, P. 1986. The forms of Capital. In Richardson, J.G. (ed.), Handbook of theory and research for the sociology of education. Westport: Greenwood Press. 


\section{Thibaut Dubarry}

Buis, H. 2007. Historic Protestantism and predestination. Eugene: Wipf and Stock.

Burchardt, M. 2016. Faith in the time of AIDS: Religion, biopolitics and modernity in South Africa. Hampshire: Palgrave Macmillan.

Burchardt, M. 2017. Diversity as neoliberal governmentality: Towards a new sociological genealogy of religion. Social Compass 64, 2: 180-193. doi: https://doi.org/10.1177/0037768617697391.

Campos, L.S. 1997. Teatro, templo e mercado: Organização e marketing de um empreendimento neopentecostal. Petrópolis: Editora Vozes.

Casanova, J.-C. (ed.) 1985. Raymond Aron: Histoire et politique. 1905-1983. Commentaire Julliard. Paris: Julliard.

Clark, M. 2015. Contemporary Pentecostal leadership: The Apostolic Faith Mission of South Africa as case study. Cyberjournal for PentecostalCharismatic Research 16: 1-14. URL: http://www.pctii.org/cyberj/ cyberj16/clark.html.

Comaroff, J. \& J. Comaroff 2000. Privatizing the millennium new Protestant ethics and the spirits of capitalism in Africa, and elsewhere. Africa Spectrum 35, 3: 293-312.

Cox, H.G. \& M. Valois 1995. Retour de Dieu: voyage en pays pentecôtiste. Cambridge: Desclée de Brouwer.

Cox, H.G. 2001. Fire from heaven: The rise of Pentecostal spirituality and the reshaping of religion in the twenty-first century. Cambridge: Da Capo Press. URL: https://books.google.fr/books?hl=en\&lr=\&id=dm 8 AgAAQBAJ\&oi=fnd\&pg=PR9\&dq=harvey + cox $+\&$ ots $=3$ Cie 60 StVE \&sig=Ngo4IUUW3ivR4jR6beuO4YpmRIU.

Cox, H.G. 2016. The market as God. Cambridge: Harvard University Press.

Da Silva, N. Jr. 2011. The liquid church: A reading of the modern church through Neo-Pentecostalism. Ciberteologia Revista Theologia \& Cultura 7, 34: 63-80.

De Certeau, M. \& L. Giard 1987. La faiblesse de croire. Paris: Seuil.

Delpuech P. \& P. Séguin 1996. Discours prononcés à l'Assemblée nationale, 1945-1976. Paris: Assemblée Nationale.

De Tocqueville, A. 2013. Democracy in America. Vol. 2. Washington: BiblioLife.

Durkheim, E. 1965. The elementary forms of the religious life by Emile Durkheim. New York: The Free Press. 
Evans, C.S. 2006. Exploring kenotic Christology: The self-emptying of God. Oxford: Oxford University Press.

Freud, S. 2012. The future of an illusion. Richter, G.C. (trans.). Pacific Publishing Studio. URL: https://www.amazon.com/Future-IllusionBroadview-Editions/dp/1554810655?asin=145153714X\&revisionId= \&format $=4 \&$ depth $=1$.

Fukuyama, F. 1992. The end of history and the last man. New York: The Free Press.

García-Ruiz, J. \& P. Michel 2012. Et Dieu sous-traita le Salut au marché: De l'action politique des mouvements évangéliques en Amérique latine. Paris: Armand Colin.

Gauchet, M. 1999. The disenchantment of the world: A political history of religion. Princeton: Princeton University Press. URL: https:// books.google.fr/books?hl=en\&lr=\&id=JGMIn1vLBi8C\&oi=fnd\&pg= PR9\&dq=marcel+gauchet $\% 27 \mathrm{~s}+$ the + disenchantment\&ots $=7 \mathrm{~s} 5 \mathrm{yCw} z \mathrm{z}$ b\&sig=E4-YeXA3YNdAkvRNUNMdkWue9wg.

Gauchet, M. 2013. L'avènement de la démocratie. Tome 3: A l'épreuve des totalitarismes (1914-1974). Paris: Éditions Gallimard. URL: https://books.google.fr/books?hl=en\&lr=\&id=iWnQhxwKpxwC\&oi=f nd\&pg=PT2\&dq=marcel+gauchet $+a v \% C 3 \%$ A8nement \&ots=MbDCY oZoHm\&sig=vrnzrbFVk15tMOBI2I_AdhMdqak.

Gauchet, M. 2014. L'avènement de la démocratie. Tome 2: La crise du libéralisme (1880-1914). Paris : Éditions Gallimard. URL: https:// books.google.fr/books?hl=en\&lr=\&id=qoeKAwAAQBAJ\&oi=fnd\&pg $=$ PT4\&dq=marcel+gauchet $+\mathrm{av} \% \mathrm{C} 3 \%$ A 8nement\&ots=JcXdEPkxkr\&si g=VRUPI0e30Muc_DT8ZoAkH-q3Bf8.

Gauchet, M. 2017. L'avènement de la démocratie. Tome 4: Le nouveau monde: L'Avènement de la démocratie IV. Paris: Éditions Gallimard.

Hackett, R.I.J. 1998. Charismatic/Pentecostal appropriation of media technologies in Nigeria and Ghana. Journal of Religion in Africa 28, 3: 258-277. URL: http://www.jstor.org/stable/1581571.

Hegel, G.W.F. 1998. Phenomenology of spirit. London: Motilal Banarsidass. Hollenweger, W.J. 1972. The Pentecostals: The charismatic movement in the churches. Augsburg: Publishing House Minneapolis.

Iannaccone, L.R. 1991. The consequences of religious market structure: Adam Smith and the economics of religion. Rationality and society 3, 
2: 156-177. doi: http://journals.sagepub.com/doi/abs/10.1177/ 1043463191003002002.

Iannaccone, L.R. 1998. Introduction to the economics of religion. Journal of Economic Literature 36, 3: 1465-1495. URL: http://www.jstor.org/ stable/2564806.

Inglehart, R. \& P. Norris 2011. Sacred and secular: Religion and politics worldwide. $2^{\text {nd }}$ ed. Cambridge: Cambridge University Press.

Interview with Baba: May 6, 2018.

Interview with Pastor Russel: June 2019.

Lange, L.W. 2005. God so loved the world: A study of Christian doctrine. Waukesha: Northwestern Publishing House.

Lewison, E. 2011. Pentecostal power and the Holy Spirit of capitalism: Reterritorialization in the charismatic cosmology. Symposia: The Journal of Religion 3, 1: 31-54. URL: https://symposia.library.utoronto.ca/ index.php/symposia/article/view/14362.

Löwith, K. 2011. Meaning in history: The theological implications of the philosophy of history. Chicago: University of Chicago Press.

Loy, D.R. 1997. The religion of the market. Journal of the American Academy of Religion 65, 2: 275-290. URL: http://www.jstor.org/ stable/1465766.

Luther, H.M., H. Gutman, \& P.H. Hutton 1988. Technologies of the self: A seminar with Michel Foucault. Cambridge: University of Massachusetts Press.

Martin, D. 1990. Tongues of fire. The explosion of Protestantism in Latin America. Oxford: Basil Blackwell.

Martin, D. 2001. Pentecostalism: The world their parish. London: John Wiley \& Sons.

Marx, K. 2014. Le capital: Critique de l'économie politique. Le procès de production du capital. Livre premier. Paris : PUF.

Marx, K. \& F. Engels 1972. The German ideology. Vol. 1. New York: International Publishers.

Massignon, L. 1922. La passion d'al-Hosayn-ibn-Mansour al-Hallaj: Martyr mystique de l'Islam, exécuté à Bagdad le 26 mars 922; étude d'histoire religieuse. Vol. 2. Paris: Geuthner.

Maxwell, D. 1998. Delivered from the spirit of poverty? Pentecostalism, prosperity and modernity in Zimbabwe. Journal of Religion in Africa 28, 3: 350-373. 
Maxwell, D. 2005. The Durawall of faith: Pentecostal spirituality in neoliberal Zimbabwe. Journal of Religion in Africa 35, 1: 4-32.

McCleary, R.M. \& R.J. Barro 2006. Religion and economy. The Journal of Economic Perspectives 20, 2: 49-72. URL: http://www.jstor.org/stable/ $\underline{30033650 .}$.

Merton, R.K. 1968. The self-fulfilling prophecy. Social theory and social structure 3: 475-490.

Meyer, B. 1999. Translating the devil: Religion and modernity among the Ewe in Ghana. Edinburgh: Edinburgh University Press.

Meyer, B. 2007. Pentecostalism and neo-liberal capitalism: Faith, prosperity and vision in African Pentecostal-charismatic churches. Journal for the Study of Religion 20, 2: 5-28.

Müller, R. 2011. African pilgrimage: Ritual travel in South Africa's Christianity of Zion. Johanesburg: Ashgate Publishing.

Ngong, D.T. 2009. Salvation and materialism in African theology. Studies in World Christianity 15, 1: 1-21. doi: https://doi.org/10.3366/ E135499010900032X.

Nietzsche, F.W. 2000. The birth of tragedy. Oxford: Oxford University Press. URL: https://books.google.fr/books?hl=en\&lr=\&id=1Fpvj1 WWeLwC\&oi=fnd\&pg=PR7\&dq=the+birth+of+tragedy+nietzsche\&o ts=d359q1H1dx\&sig=zOQhmtcoKhpUlByMG6f3J8fxgSs.

Nietzsche, F.W. 2011. Dawn: Thoughts on the presumptions of morality. Vol. 5. Stanford: Stanford University Press.

Pastor Russel. 2015. WhatsApp message.

Peterson, R.A. \& M.D. Williams 2010. Why I am not an Arminian. New York: InterVarsity Press.

Piketty, T. 2017. Capital in the twenty-first century. Harvard: Harvard University Press.

Polanyi, K. 1957. The great transformation: The political and economic origin of our time. London: Beacon Press.

Rodinson, M. 1978. Islam and capitalism. Austin: University of Texas Press.

Schmitt, C. 1985. Political theology: Four chapters on the concept of sovereignty. Chicago: University of Chicago Press.

Schmitt, C. 2008a. Constitutional theory. Duke: Duke University Press.

Simmel, G. \& K.H. Wolff 1964. The sociology of Georg Simmel. New York: Collier-Macmillan. 


\section{Thibaut Dubarry}

Stark, R. \& R. Finke 2000. Acts of faith: Explaining the human side of religion. Berkeley University of California Press. URL: https://books. google.fr/books?hl=en\&lr=\&id=91309xcpBB4C\&oi=fnd\&pg=PA1\&d $\mathrm{q}=$ Rodney+Stark\&ots=vh-MXG4Zkz\&sig=GdwamB3crxRDl0hyQUG H7CUB5-4.

Stark, R. \& W.S. Bainbridge 1996. A theory of religion. New York: Rutgers University Press.

Taylor, C. 2007. A secular age. Harvard: Harvard University Press.

Tönnies, F. 1957. Community and society. Mineola: Dover Publications. URL: $\quad$ https://archive.org/stream/in.ernet.dli.2015.200858/2015. 200858.Community-_djvu.txt.

Troeltsch, Ernst. 2018. Religion et Histoire. Genève: Labor et Fides.

Warner, R.S. 1993. Work in progress toward a new paradigm for the sociological study of religion in the United States. American Journal of Sociology 98, 5: 1044-1093. doi: http://www.journals.uchicago.edu/ doi/abs/10.1086/230139.

Weber, M. 1993. The sociology of religion. New York: Beacon Press.

Weber, M. 2010. Ancient Judaism. New York: Simon and Schuster.

Weber, M. 2013. Economy and society. Berkeley: University of California Press.

Prof Thibaut Dubarry

Department of Sociology

University of Rouen

thibaut.dubarry@gmail.com 